\title{
Therapeutic Plasma Exchange in Tanta University Hospitals, Single Center Experience
}

\author{
HANAA I. OKDA, M.D.; SHIMAA H. EL-ATTAR, M.D. and ALZAHRAA A. ALLAM, M.D. \\ The Department of Internal Medicine, Faculty of Medicine, Tanta University, Tanta, Egypt
}

\begin{abstract}
Background: Therapeutic Plasma Exchange (TPE) is effective therapeutic procedure in treating diverse diseases.

Aim of Study: To evaluate the outcomes of TPE in different diseases in our department.

Patients and Methods: Retrospective study of patients referred for TPE during last five years period. We reviewed the demographic, clinical indications, number of sessions, volume of exchanged plasma, patient response and complications during or after the procedure and descriptive statisticalanalysis was performed.

Results: The study included 109 patients recorded during the last 5 years period. The indications for TPE were GullianBaree in 28 patients with response in (21/28 pateints), thrombotic microangiopathy in 27 patients with response in $(19 / 27)$ patients, SLE in 22 patients with response in (16/22), Cryoglobinemia in 12 patients with response in (10/12), RPGN in 5 patients with response in $(4 / 5)$ patients, hyperviscosity in 6 patients, mythenia gravis in 4 patients, renal transplantation in 3 patients, dermatomyocitis in one patient and autoimmune hemolytic anemia in one patient with complete response in all patients of these later diseases. The main complications of the procedure were muscle cramps induced by hypocalcemia $(\mathrm{n}=10,9 \%)$, allergic reactions $(\mathrm{n}=9,8 \%)$, hypotension $(\mathrm{n}=7$, $6 \%)$, fever $(n=4,3.6 \%)$, loss of consciousness $(n=2,1.8 \%)$, convulsions $(n=2,1.8 \%)$, catheter related hematoma $(n=1$, $0.9 \%)$, bleeding from AV fistula $(\mathrm{n}=1,0.9 \%)$.

Conclusion: Our experience in therapeutic plasma exchange showed favorable results in different immunological and non-immunological diseases.
\end{abstract}

Key Words: Therapeutic exchange - Cryoglobuinemia Thrombotic microangiopathy.

\section{Introduction}

THERAPEUTIC Plasma Exchange (TPE) is an effective therapeutic procedure for different renal, hematological, rheumatological, neurological, oncological and othermultisystemic diseases especially for patients with diseases refractory to traditional

Correspondence to: Dr. Hanaa I. Okda, E-Mail: hanaa omar2003@yahoo.com treatments [1]. Waldenstrom'smacroglobulinemia was the first disease treated by TPE in 1962 [2] The main indications forplasma exchange is to remove high molecular weight substances like antibodies, immune complexes, etc. from the plasma and/or supplementing plasma with the missing essential factors [3].

Therapeutic Plasma Exchange (TPE) can be made by cytocentrifuge or membrane separation techniques. The use of membrane separation technique together with hemodiafiltrationtechnique has gained increasing popularity because of being a relatively easy procedure [4]

The complications may be related to the procedure itself orthe access which may be either central venous catheter or arteriovenous fistula. The large extracorporeal blood volume and blood loss in the circuit may be associated with increased risk of hypotension and anemia, respectively. Also, the risks of blood born infection increase with product transfusion during the procedure in addition to transfusion-related acute lung injury. Furthermore, access-related complications are also reported and include thrombosis and infection [5]

Through this paper we aim to document our experience in the use of TPE in treating different immune and non-immune mediated diseases.

\section{Patients and Methods}

This retrospective study was conducted at Internal Medicine Department, Tanta University Hospitals. We analyzed data of 109 patients who were treated with TPE between January 2013 and July 2018 by centrifuge and membrane separation techniques. The indications of TPE were judged according to the relevant guidelines of the underlying disease. 
Patient files were reviewed and data on demographic data (age, sex, underlying disease, laboratory parameters, volume and the type of replacement fluid used for TPE (fresh frozen plasma or human albumin), complications related to the procedure, immunosuppressive drugs, concurrent hemodialysis (HD) requirement, and the number of TPE sessions were collected. All patients or the patient's relatives had given written consent before the TPE after informing them about the steps and complications related to the procedure.

Plasmapheresis was performed using a centrifuge technique (Cobe Spectra) for 97 patients and Prismaflux machine for 12 patients via using 14 French double lumen dialysis catheters placed to 106 patients and via arteriovenous fistula in 3 patients. Hemodynamic parameters were monitored throughout the procedure. TPE was performed 2 to 3 times weekly using a single volume plasma exchange except for 8 patients with TTP who received daily sessions. The patient's plasma volume was calculated using the following formula: Plasma volume $(\mathrm{L})=$ Weight $\mathrm{X} 0.065 \mathrm{X}(1-$ hematocrit) [6]. We used 20\% human albumin (diluted to $5 \%$ albumin in isotonic saline) and/or Fresh Frozen Plasma (FFP) as the replacement fluid. Anticoagulation with Acid citrate dextrose solution (ACD) by infusion rate $(1-1.8 \mathrm{mg} / \mathrm{kg} / \mathrm{min})$ was used in 84 patients while heparin was used in 25 patients (1000 units loading dose followed by 500 unit/hour) [7]. To avoid hypocalcemia in patients treated with ACD, $20 \mathrm{ml} 10 \%$ calcium gluconate diluted to $50 \mathrm{ml}$ in $0.9 \%$ sodium chloride solution given over the treatment period in the venous limb of the circuit [8].

Patient's vital signs, complete blood counts, electrolytes, serum proteins and coagulation profile were evaluated and any abnormal parameters were corrected firstly. A careful monitoring of hemodynamic parameters was done during the procedure.

Indications for TPE, number of sessions and duration of each, volume of plasma exchanged and patient tolerance to the procedure were recorded. All patients received additional medical therapy including immunosuppressant according to original disease indication in collaboration with the referring departments were recorded.

The response to treatment was either complete remission when there was improvement of all the clinical, laboratory and pathological abnormalities after adequate number of TPE or no remission in patients without improvement in clinical and laboratory abnormalities after at least five TPE sessions and in patients with an initial response with recurrence after cessation of TPE or partial response when clinical and laboratory results not fitting into any one of the above mentioned groups.

\section{Statistical analysis:}

All the findings were recorded. Values of continuous variables were expressed as mean \pm SD. Categorical variables were expressed as number and percentages and comparative studies were done using SPSS for Windows, Version 23.0 (SPSS Inc., Chicago, IL, USA).

\section{Results}

Our study included 109 patients [32 male (29.4\%) and 77 female (70.6\%)] recorded in 5 years period. The mean age was $37.75 \pm 11.98$ years (range: 14-64 years). A total of 620 TPE sessions were performed. Eight patients $(7.2 \%)$ required daily therapy while 101 patient $(92.8 \%)$ received TPE every other day. The replacement fluid used was FFP in 100 patients $(91.7 \%)$ while albumin was used in 9 patients $(8.3 \%)$ only.

The indications for TPE in our study were Gullian Baree in 28 patients (25.7\%), Thrombotic Microangiopathy (TMA) in 27 patients (24.8\%) (15 of them were pregnancy related, 8 had TTP, 2 had typical Hemolytic Uremic Syndrome (HUS) with neurological complications, one secondary to singet cell carcinoma and one due to malignant hypertension), 22 Systemic Lupus Erythrematosus (SLE) cases (20.1\%) 12 of them had lupus cereberitis, 3 had pulmonary hemorrhage, 3 had lupus nephritis, 3 had catastrophic antiphospholipid syndrome and one had severe retinal vasulitis. Cryoglobulinemia in 12 patients due to hepatitis $\mathrm{C}$ viral infection (11\%), hyperviscosity in 6 patients $(5.5 \%) 4$ of them were secondary to multiple myloma and 2 cases secondary to waldenstorm macroglobuinemia, Rapidly Progressive Glomerulonephritis (RPGN) in 5 patients (4.6\%), myasthenia gravis in 4 patients $(3.6 \%)$, renal transplantation with acute rejection in 3 patients $(2.7 \%)$, dermatomyositis in one patient $(0.9 \%)$ and autoimmune hemolytic anemia in one patient $(0.9 \%)$ Fig. (1).

The complications of the procedure included muscle cramps which were induced by hypocalcemia $(10,9 \%)$, allergic reactions $(9,8 \%)$, hypotension $(7,6 \%)$, fever $(4,3.6 \%)$, loss of consciousness $(3,2 \%)$, convulsions $(2,1.8 \%)$, arrest in session $(2,0.9 \%)$, catheter related hematoma (1, $0.9 \%)$, bleeding from AV fistula $(1,0.9 \%)$. No complications were observed in $65 \%$ of patients (Table 1). 
Additional treatment with steroids, cyclophosphamide, IVIG, chemotherapy were noted in $82 \%$ of the patients.

\section{Outcomes of TPE in the study:}

Fifty patients $(45 \%)$ patients had complete remission, 35 (33\%) had partial remission, 14 $(13 \%)$ had no remission and $10(9 \%)$ patients died during the treatment period. The cause of death was acute respiratory failure in five patients, sepsis and multi organ failure in 2 patients while 2 patients arrested during session and one patient died due to massive retroperitoneal hematoma.

\section{Need for $H D$ :}

All of the patients with RPGN ( $\mathrm{n}=5), 12(55 \%)$ of patients with SLE, $16(59 \%)$ of patients with TMA, $3(60 \%)$ of the patients with multiple myeloma, $3(25 \%)$ of patient with cryoglobulinemia, one $(50 \%)$ of the patients with HUS, $2(66 \%)$ of patients with renal trans-plantation concurrently required $\mathrm{HD}$ at the time of diagnosis. TPE and HD were usually done on alternate days. $20 \%$ of patients with RPGN, $42 \%$ of patients with SLE $25 \%$ of patients with TMA $20 \%$ of patients with myloma remained HD dependent. Outcome of the patients according to the primary disease and need for HD are presented in (Table 2).

\section{Biochemical changes after TPE:}

A significant increase was found in platelet count after TPE in patients with thrombotic microangiopathy $(p<0.001)$. Furthermore, there was a statistically significant fall in Lactate Dehydrogenase (LDH) levels in the same group $(p<0.001)$. Creatinine level decreased after TPE in TMA, RPGN, renal transplantation and lupus nephritis patients $(p<0.001)$ and proteinuria levels improved after TPE in TMA, RPGN and lupus nephritis patients $(p=0.012)$ (Table 3$)$.

Table (1): Complication of TPE and additional treatment for the patients.

\begin{tabular}{|c|c|c|c|c|}
\hline \multirow{2}{*}{ Diagnosis $(\mathrm{N})$} & \multirow{2}{*}{ Additional treatment $(\mathrm{N})$} & \multicolumn{3}{|c|}{ Complications (N) } \\
\hline & & None (71) & Non-life threating (35) & Life threating (3) \\
\hline - Gullian Barre (28) & $\begin{array}{l}\text { Steroids (28) } \\
\text { IVIG (8) }\end{array}$ & None (23) & $\begin{array}{l}\text { Hypotension (2) } \\
\text { Allergic reactions (2) } \\
\text { Fever (1) }\end{array}$ & 0 \\
\hline • TMA (27) & $\begin{array}{l}\text { None (19) } \\
\text { Pulse steroids (5) } \\
\text { Pulse steroid + Cylophophamide (3) } \\
\text { Pulse steroid + Rituximab (1) }\end{array}$ & None (14) & $\begin{array}{l}\text { Allergic reaction (3) } \\
\text { Muscle cramps (3) } \\
\text { Fever (2) } \\
\text { Loss of consciousness (2) } \\
\text { Hypotension (2) }\end{array}$ & Convulsions (1) \\
\hline - $\operatorname{SLE}(22)$ & Pulse steroids + cyclophosphamide (22) & None (15) & $\begin{array}{l}\text { Allergic reaction (2) } \\
\text { Muscle cramps ( } 3 \text { ) }\end{array}$ & Arrest (2) \\
\hline $\begin{array}{l}\text { - Cryoglobinemia } \\
\text { (12) }\end{array}$ & $\begin{array}{l}\text { Pulse steroids (5) } \\
\text { Pulse steroids }+ \text { antiviral } \\
\text { treatment for HCV (4) }\end{array}$ & None (8) & $\begin{array}{l}\text { Allergic reaction (2) } \\
\text { Muscle cramps (1) } \\
\text { Catheter related hematoma (1) }\end{array}$ & 0 \\
\hline $\begin{array}{l}\cdot \text { Hyperviscosity } \\
\text { (6) }\end{array}$ & $\begin{array}{l}\text { VAD }(1) \\
\text { Bortozemab }+ \text { dexa }(2) \\
\text { Lenolide }+ \text { dexa }(2) \\
\text { CHOP }(1)\end{array}$ & None (3) & $\begin{array}{l}\text { Hypotension (1) } \\
\text { Fever (1) } \\
\text { Loss of consciousness (1) }\end{array}$ & 0 \\
\hline • RPGN (5) & Pulse steroids + cyclophosphamide (5) & None (3) & $\begin{array}{l}\text { Muscle cramps (1) } \\
\text { Hypotension (1) }\end{array}$ & 0 \\
\hline $\begin{array}{l}\text { - Myasthenia gravis } \\
\text { (4) }\end{array}$ & $\begin{array}{l}\text { Steroids (1) } \\
\text { Steroids + IVIG (2) } \\
\text { Steroids + IVIG + thymectomy (1) }\end{array}$ & None (3) & Muscle cramps (1) & 0 \\
\hline $\begin{array}{l}\text { - Renal transplanta- } \\
\text { tion with acute re- } \\
\text { jection (3) }\end{array}$ & $\begin{array}{l}\text { Pulse steroids + rituximab (1) } \\
\text { Steroids + IVIG (1) } \\
\text { Steroids + cyclosporine (1) }\end{array}$ & None (1) & $\begin{array}{l}\text { Muscle cramps (1) } \\
\text { Bleeding from AV fistula (1) }\end{array}$ & 0 \\
\hline $\begin{array}{l}\text { - Dermatomyositis } \\
\text { (1) }\end{array}$ & Steroids (1) & 0 & Hypotension (1) & 0 \\
\hline • AIHA (1) & Steroids (1) & None (1) & 0 & 0 \\
\hline
\end{tabular}


Table (2): Outcomes of the patients according to the primary disease and need for HD.

\begin{tabular}{lllllll}
\hline & \multicolumn{5}{c}{ Outcome (\%) } \\
\cline { 2 - 5 } Diagnosis (N) & CR & PR & NOR & Died & \\
\hline Gullian Barre (28) & $39 \%$ & $37 \%$ & $14 \%$ & $10 \%$ & NO (0) \\
TMA (27) & $37 \%$ & $33 \%$ & $18 \%$ & $12 \%$ & NO (16), Temprorary (12), Chronic (4) \\
SLE (22) & $36 \%$ & $36 \%$ & $18 \%$ & $10 \%$ & No (12), Chronic (5), Temporary (7) \\
Cryoglobinemia (12) & $50 \%$ & $33 \%$ & 0 & $17 \%$ & No (3), Temporary (3) \\
Hyperviscosity (6) & $83 \%$ & $17 \%$ & 0 & 0 & No (3), Temporary (2), Chronic (1) \\
RPGN (5) & $60 \%$ & $20 \%$ & $20 \%$ & 0 & No (5), Temporary (4), Chronic (1) \\
Mythenia gravis (4) & $100 \%$ & 0 & 0 & 0 & 0 & \\
Renal transplantation (3) & $66 \%$ & $34 \%$ & 0 & 0 & 0 & \\
Dermatomyositis (1) & $100 \%$ & 0 & 0 & 0 & 0 & \\
AIHA (1) & $100 \%$ & 0 & 0 & 0 & 0 & PR : Partial Remission. \\
RPGN : Rapidly Progressive Glomerulonephritis. & & & CR : Complete Remission. \\
TMA : Thrombotic Microangiopathy. & & & No R : No Response. \\
SLE : Systemic Lupus Erythematosus. & & & N : Number of patients. \\
HD : Hemodialysis, hemodialysis. &
\end{tabular}

Table (3): Relevant biochemical changes before and after TPE.

\begin{tabular}{lclll}
\hline & $\begin{array}{c}\text { Patients } \\
(\mathrm{N})\end{array}$ & $\begin{array}{c}\text { Before TPE } \\
(\text { mean } \pm \mathrm{SD})\end{array}$ & $\begin{array}{c}\text { After TPE } \\
(\text { mean } \pm \mathrm{SD})\end{array}$ & $p$ \\
\hline Platelet $\left(10^{9} / \mathrm{L}\right)$ & 27 & $38.3 \pm 24.7$ & $152.1 \pm 33.5$ & $<0.001$ \\
LDH $(\mathrm{U} / \mathrm{L})$ & 27 & $984.9 \pm 372.9$ & $286.6 \pm 47.18$ & $<0.001$ \\
Creatinine $(\mathrm{mg} / \mathrm{d})$ & 38 & $5.4 \pm 2.1$ & $2.1 \pm 1.2$ & $<0.001$ \\
Proteinuria in 24 hours $(\mathrm{mg})$ & 38 & $2850 \pm 1318$ & $1081 \pm 643$ & 0.012 \\
\hline
\end{tabular}

LDH: Lactic Dehydrogenase.

SD: Standard Deviation.

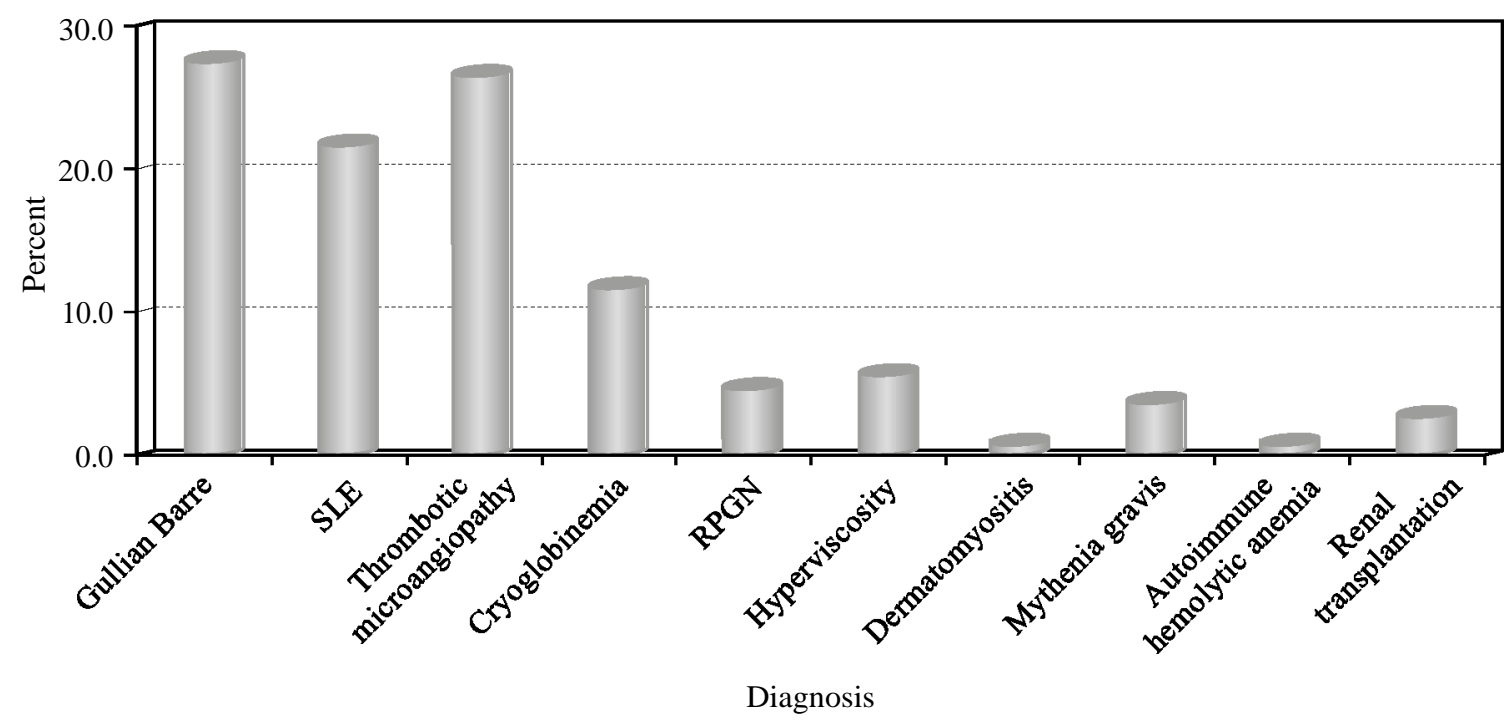

Fig. (1): Indications of TPE in the study.

\section{Discussion}

Therapeutic Plasma Exchange (TPE) is an extracorporeal blood purification procedure indicated for the removal of large molecular weight substances from the plasma or supplement plasma with the missing essential factors [9]. TPE has a proven efficacy in treatment of different immune and non- immune diseases refractory to conventional treatments [10].

Guillain-Barre syndrome (GB) is a subacute polyneuropathy with immune-mediated mechanism. It is characterizedby progressive symmetric flaccid paralysis and loss of deep tendon reflexes [11]. Our study included 28 patients with GB syndrome 
(25.7\%). 10 patients showed complete remission and 11 patients showed partial remission that documented clinically by sensory and motor examinations and by nerve conduction studies while 4 patients showed no remission after plasma exchange with persistence of muscle weakness. 3 patients died during treatment course and the main causes of death was sepsis due to ventilator acquired pneumonia.

Our results were in agreement with Meena Sidhu et al., [12] who showed an overall response rate of $77 \%$ at the end of 10 days follow-up period in the study that included 18 cases of GB syndrome. Complete response was noted in 11 cases $(61 \%)$, partial response in 3 cases (16\%), no response in 4 cases $(22 \%)$ NobuhiroYuki et al., [13] stated improvement rate at (87\%) while Hughes et al., [14] stated higher improvement rate at (97\%). Our results support the initiation of treatment early within the first week which decrease recovery time and support early achievement of clinical milestones.

The study included 22 patients with SLE $(20.1 \%)$. The main indications were lupus cerebritis in 12 patients while the other indications were pulmonary hemorrhage in 3 patients, lupus nephritis in 3 patients, catastrophic antiphospholipid syndrome secondary to lupus in 3 patients and only one had lupus induced severe retinal vasulitis. Our results showed complete remission in 8 patients, partial remission in 8 patients while 4 patients showed no remission and 2 patients died during treatment course. The American Society for Apheresis (ASFA) classified Lupus nephritis is as Category IV as a controlled trial of TPE plus prednisone and cyclophosphamide versus prednisone and cyclophosphamide in severe lupus nephritis showed no benefit. However they support TPE use in sever lupus cerebritis as category II [15]

Our study included 6 patients $(5.5 \%)$ with hyperviscosity mainly due to multiple myeloma in 4 patients and waldenstrom macroglobinemia in only 2 cases. The results supported use of TPE in hyperviscosity as 5 patients achieved complete remission while one patient achieved partial remission. This was in agreement with the results of Zarkovic et al., [16], and Stone MJ [17] who stated that single plasmapheresis procedures with one plasma volume replacement showed a dramatic improvement in such patients.

Cryoglubinemic cases represented in 12 patients (11\%) due to HCV virus infection. They showed complete remission in 6 cases and partial remission in 4 cases while 2 patients died during treatment course. 5 cases needed pulse steroid and 5 cases needed pulse steroid and cyclophosphamide while 4 patients received antiviral therapy during course of treatment. In disagreement to our results, Rockx MA and Clark WF reviewed 11 studies over the past 20 years for evidence supporting or refuting the reported use of plasmapharesis for cryoglobulinemia (January 1988 through June 2008) and concluded that these studies weakly support the use of plasma exchange largely on a mechanistic basis [18].

Autoimmune Hemolytic Anemia (AIHA) can be classified into either warm AIHA and cold agglutinin syndrome. According to the ASFA criteria, warm autoimmune hemolytic anemia is in category III, and cold agglutinin disease is in category II, indicating weak evidence [15]. Our study included only a case of warm autoimmune hemolytic anemia that showed complete remission with steroid treatment and TPE. Our results were in agreement with Takahashi et al., in his case report of a refractory auto immune hemolytic anemia that did not respond to steroid only. The patient symptoms rapidly improved after starting TPE [19]

Myasthenia Gravis (MG) is an autoimmune disease characterized by presence of antibodies that attacking postsynaptic nicotinic acetylcholine receptors and presented with fluctuating weakness that may progress to life-threatening complications [20]. The study included 4 cases with myasthenia gravis that showed marvelous response after starting TPE ( $100 \%$ remission rate). The role of TPE in the treatment of MG was reported in other studies. Ghonemy et al., [21] stated improvement rate at $81.25 \%$ in their study that included $16 \mathrm{MG}$ cases. Also, Nagayasu et al., [22] who stated remission rate at 79\%, and Sarkar et al., [23] who stated remission rate of $80 \%$ supported use of TPE in the treatment of MG. Moreover, ASFA supported TPE use in the treatment of MG as category I [15]

Dermatomyositis (DM) is antibody mediated type of of idiopathic inflammatory myopathy. The antibodies include ANA, anti-Ro, anti-La, antiSm, anti-ribonucleoprotein, or myositis-specific antibodies. It is assosciated with high morbidity and mortality [15]. Although our case of dermatomyositis showed complete remission after starting TPE, ASFA categorized use of TPE as category IV, grade 2A [15]

Rapidly progressive glomerulonephritis (RPGN) is a disease of the kidney characterized clinically 
by a rapid decrease in the Glomerular Filtration Rate (GFR) of at least $50 \%$ over a short period, from a few days to 3 months. The main pathologic finding is extensive glomerular crescent formation. The ubiquitous pathological feature of crescentic glomerulonephritis is a focal rupture of glomerular capillary walls that can be seen by light microscopy and electron microscopy [24]. Our study included 5 cases of RPGN due to pauci immune glomerulonephritis. The patient received immunosuprresive drugs in the form of steroid and cyclophosphamide. The patient received TPE and showed complete remission in 3 cases, partial remission in one patient, no remission in one patient Hemodialysis sessions were started based on clinical and laboratory indications. 4 patients received temporary HD while one patient remained dialysis dependent. The role of TPE in treatment of RPGN was documented in many studies. Sengul et al., reported partial remission in 12 cases and complete remission in only one case. However, they showed significant reduction of creatinine after TPE ( $p=$ 0.006) [25].

Harada $\mathrm{T}$ et al., examined the efficacy of plasma exchange in patients with Rapidly Progressive Glomerulonephritis (RPGN) and concluded that plasmapheresis, when used in combination with immunosuppressive drugs lead to improvement of renal functions [26].

Three cases of renal transplant antibody mediated rejection were included in our study. They received TPE in addition to immunosuppression. Two cases showed complete remission with improved renal functions however one patient achieved partial remission. The ASFA guidelines supported use of TPE in antibody mediated rejection and categorized it as category I grade 1B [15] .

Our study included 27 case of thrombotic microangiopathy secondary to TTP, HUS, pregnancy related, singet cell carcinoma and malignant hypertension. After TPE, 10 patient achieved complete remission, 9 patients achieved partial remission, 5 patients did not respond to TPE and 3 patients died during treatment course. 12 patients needed temporary HD while 4 patients became dialysis dependent. Randomized clinical trials comparing TPE with plasma transfusion in TTP/HUS therapy support use of TPE even when equal volumes of plasma were used in both procedures [27] .

\section{Conclusion:}

A 5-year Tanta University Hospitals experience in therapeutic plasma exchange shows TPE is effective procedure the most favorable results were recorded in hyperviscosity syndrome, myasthenia gravis, dermatomyositis, autoimmune hemolytic anemia followed by renal transplantation, RPGN, Cryoglobinemia, Gullian Baree, SLE and thrombotic microangiopathy. Additionally it is considered to be a safe procedure. No complications related to session were recorded in $65 \%$ of patients. The most common complications were muscle cramps followed by minor allergic reactions. Therapeutic plasma exchange is effective and safe procedure for treatment of different diseases. Many other studies were needed to uncover its role in other rare diseases like dermatomyositis and autoimmune hemolytic anemia.

\section{Conflict of interest:}

The outhers showed no conflict of interest.

\section{References}

1- PONS-ESTEL G.J., SALERNI G.E., SERRANO R.M., GOMEZ-PUERTA J.A., PLASIN M.A., et al.: Therapeutic plasma exchange for the management of refractory systemic autoimmune diseases: Report of 31 cases and review of the literature Autoimmunity rev., 10 (11): 679-84, 2011.

2- SCHWAB P.J. and FAHEY J.L.: Treatment of Waldenstrom'smacroglobulinemia by plasmapheresis. N. Engl. J. Med., 263: 574-79, 1960.

3- NAKANISHI T., SUZUKI N., KURAGANO T., NAGASAWA Y. and HASUIKE Y.: Current topics in therapeutic plasmapheresis. Clin. Exp. Nephrol., 18 (1): 41 9, 2014.

4- AYDIN Z., GURSU M., KARADAG S., UZUN S., TATLI E., SUMNU A., et al.: Role of plasmapheresis performed in hemodialysis units for the treatment of anti-neutrophilic cytoplasmic antibody-associated systemic vasculitides. Ther. Apher. Dial., 15 (5): 493-8, 2011.

5- MICHON B., MOGHRABI A., WINIKOFF R., BARRETTE S., BERNSTEIN M.L., et al.: Complications of apheresis in children. Transfusion, 47 (10): 1837-42, 2007.

6- SZCZEPIORKOWSKI Z.M., WINTERS J.L., BANDARENKO N., et al.: Linenbergerin clinical practiceevidence-based approach from the ApheresisApplications Committee of the American Society for Apheresis. J. Clin. Apher., 25 (3): 83-177, 2010.

7- LEE G. and AREPALLY G.M.: Anticoagulation techniques in apheresis: From heparin to citrate and beyond. J. Clin. Apher., 27 (3): 117-25, 2012.

8- WEINSTEIN R.: Prevention of citrate reactions during therapeutic plasma exchange by constant infusion of calcium gluconate with the return fluid. J. Clin. Apher., 11 (4): 204-10, 1996

9- KAPLAN A.A.: Therapeutic plasma exchange: Core curriculum Am. J. Kidney Dis., 52: 1180-96, 2008.

10- ROCK G.A., SHUMAK K.H., BUSKARD N.A., et al.: Comparison of plasma exchange with plasma infusion in 
the treatment of thrombotic thrombocytopenic purpura Canadian apheresis study group. N. Engl. J. Med., 325: 393-7, 1991.

11- MAZEN M.D. and RICHARD J.B.: Guillain-Barré Syndrome and Variants. Neurol. Clin., May, 31 (2): 491-510, 2013.

12- SIDHU M., DOGRA A. and KUMAR D.: Clinical efficacy and applications of therapeutic plasma exchange: A tertiary care center experience from Jammu. Asian J. Transfus. Sci., 9 (1): 106, 2015.

13- HUGHES R.A., SWAN A.V., RAPHAËL J.C., ANNANE D., VAN KONINGSVELD R., et al.: Immunotherapy for Guillain-Barré syndrome: A systematic review. Brain, 130 (Pt 9): 2245-57, 2007.

14- YUKI N. and HARTUNG H.P.: Guillain-Barré Syndrome. N. Engl. J. Med., 366 (24): 2294-304, 2012.

15- SCHWARTZ J., WINTERS J.L., PADMANABHAN A., BALOGUN R.A., DELANEY M., LINENBERGER M.L., et al.: Guidelines on the use of therapeutic apheresis in clinical practice-evidence-based approach from the Writing Committee of the American Society for Apheresis: The sixth special issue. J. Clin. Apher., 28 (3): 145-284, 2013.

16-ZARKOVIC M. and KWAAN H.C.: Correction of hyperviscosity by apheresis. Semin. Thromb. Hemost., 29 (5): 535-42, 2003.

17- STONE M.J. and BOGEN S.A.: Role of Plasmapheresis in Waldenström's Macroglobulinemia. Clin. Lymphoma Myeloma Leuk., 13 (2): 238-40, 2013.

18- ROCKX M.A. and CLARK W.F.: Plasma exchange for treating cryoglobulinemia: A descriptive analysis. Transfus. Apher. Sci., 42 (3): 247-51, 2010.

19- TAKAHASHI T., HARA T., SHIMOMURA Y., YOSHIKAWA T. and TOMITA E.: Plasmapheresis for fulminant autoimmune hemolytic anemia with rapidly progressing disturbance of consciousness. Rinsho. Ketsueki., 47 (8): 787-9, 2006.

20- McGROGAN A., SNEDDON S. and De VRIES: The incidence of myasthenia gravis: A systematic literature review. CS Neuroepidemiology, 34 (3): 171-83, 2010.

21- TAREK A. GHONEMY, EBRAHIM M. SALIM, SALAH F. ELSAYED and AMIR M. ELOKELY: Outcomes of Therapeutic Plasma Exchange; One Year Single Center Experience Urol. Nephrol. Open Access. J., 3 (5): 00096. DOI: 10.15406/unoaj.2016.03.00096, 2016.

22- NAGAYASU T., YAMAYOSHI T., MATSUMOTO K., IDE N., HASHIZUME S., et al.: Beneficial effects of plasmapheresis before thymectomy on the outcome in myasthenia gravis. Jpn. J. Thorac. Cardiovasc. Surg., 53 (1): 2-7, 2005.

23- SARKAR B.K., SENGUPTA P. and SARKAR U.N.: Surgical outcome in thymic tumors with myasthenia gravis after plasmapheresis-a comparative study. Interact Cardiovasc. Thorac. Surg., 7 (6): 1007-10, 2008.

24- SANCHEZ A.P. and WARD D.M.: Therapeutic apheresis for renal disorders. Semin. Dial., 25 (2): 119-31, 2012.

25- NILAY SENGULSAMANCI A., MESUT AYER B., MELTEMGURSU C. and MUHLISCEMARD: Transfusion and Patients treated with therapeutic plasma exchange: A single center experience Apheresis Science, 51: 83-9, 2014.

26- HARADA T., OZONO Y., MIYAZAKI M., SASAKI O., MIYAZAKI K., et al.: Plasmapheresis in the treatment of rapidly progressive glomerulonephritis. Ther. Apher., Nov., 1 (4): 366-9, 1997.

27- SURBHI DIXIT, ASEEM KUMAR TIWARI, PRASHANT KUMAR PANDEY, and VIMARSHRAINA: Successful outcome of therapeutic plasma exchange in postpartum haemolytic-uraemic syndrome: A case reportBlood Transfus., 10 (4): 533-5, 2012. 


\title{
تبادل البلازما العلاجية فى مستشفيات جامعة طنطا، تجرية المركز الواحل
}

\author{
الخلفيدة: يعد تبادل البلازما العلاجية إجراء علاجى فعال فى علاج الآمراض المختلة. \\ الهدف من الدراسة: تقييم نتائج البلازما العلاجية فى آمراض مختلفة فى قسمنا .
}

المرضى وطرق الدراسة: لقد تمت الدراسة بآثر رجعى على المرضىى الحاليين للبلازما العلاجية خلال فترة السنوات الخمس الماضية.

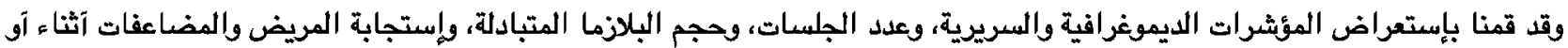

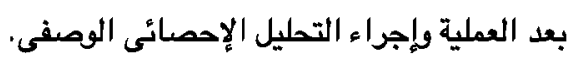

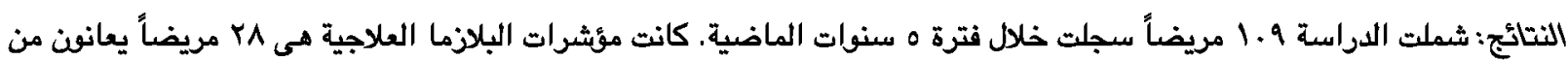

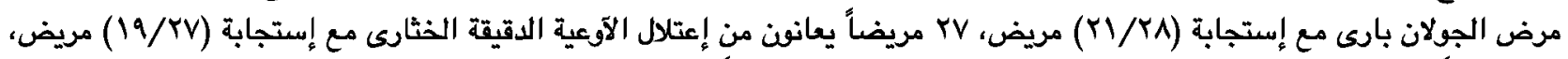

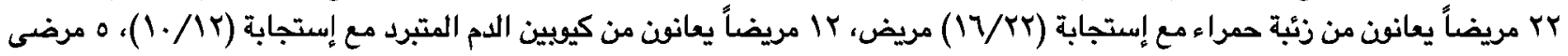

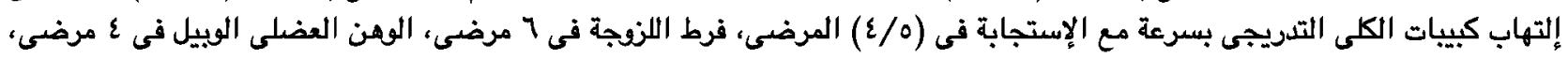

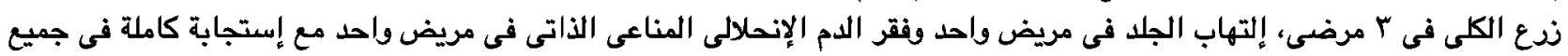

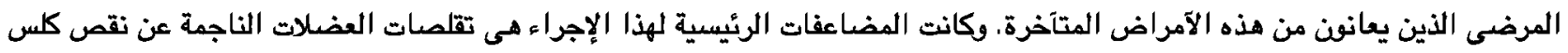

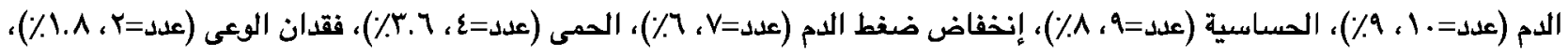

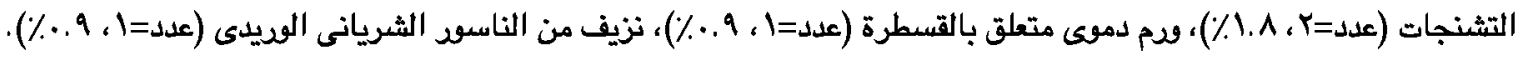
الخلاصة: آظهرت تجريتا فى تبادل البلازما العلاجية نتائج إيجابية فى مختلف الآمراض المناعية وغير المناعية. 